\title{
COMMUNICATIONS ACT AMENDMENTS, 1952- AN ATTEMPT TO LEGISLATE ADMINISTRATIVE FAIRNESS
}

\author{
BEN C. FISHER* \\ I \\ INTRODUCTION
}

On July 16, I952, the "Communications Act Amendments, 1952," popularly referred to as the "McFarland Act Amendments," became law." After more than five years of experience under this major procedural revision of the Communications Act of 1934 , as amended, it is time to appraise the effectiveness of the new provisions, as applied and interpreted by the Federal Communications Commission and the courts. When the amendments were adopted in 1952, high hopes were held by Congress and the bar that these important procedural revisions of the basic statute would bring new clarity to the law, new dispatch and expedition of matters before the Commission, and most important of all, more judicious and fairer treatment of litigants in adjudicatory proceedings.

The Communications Act Amendments, 1952, were the product of more than a decade of investigations, studies, and hearings. All segments of the broadcasting industry, as well as other interested parties, participated in formulating this "new look" in Commission proceedings. Though there was considerable disagreement by the Commission with a few provisions of the new amendments, generally the parties who participated were enthusiastic about the benefits to be gained. ${ }^{2}$ The Senate Committee Report had this to say: ${ }^{3}$

Your Committee is strongly of the opinion that enactment of the bill is a major step forward in the evolution of the regulation of radio and wire communications, both broadcast and common carrier. It believes that the legislation will be of inestimable value in making more certain that regulation of the industry shall be in "the public interest, convenience, and necessity."

Have the Commission and the public benefited substantially, as anticipated by Congress and the bar? The answer to this question would seem to be "No." In fact, in some major respects, the new amendments have caused more administrative problems and greater hardship to litigants. Before setting forth the support for

* A.B. 1948, University of Illinois; LL.B. 195I, Harvard University. Member of the District of Columbia bar.

${ }^{1} 66$ STAT. 7rr, 47 U.S.C. $\$ 153$ (1952). The basic act is the Communications Act of 1934, 48 STAT. $106_{4}, 47$ U.S.C. $\$ 15$ I et seq. (1952).

${ }^{2}$ See, e.g., Wall and Jacob, Communications Act Amendments, 1952-Clarity or Ambiguity, 41 Gro. L. J. 135, 179 (1953); Committee on Interstate and Foreign Commerce, Communications Act Amendments, 1952, H.R. REP. No. 1750, 82d Cong., 2d Sess. (1952).

${ }^{3}$ Committee on Interstate and Foreign Commerce, Communications Act Amendments, 1951, S. Rep. No. 44, 82d Cong., Ist Sess. 3 (r95 $\mathrm{r}$ ). 
this thesis, it would be well to describe briefly the salient procedural changes or clarifications resulting from the I952 amendments. No attempt will be made to describe them all. A listing of the high points is enough to demonstrate the purpose and scope of the 1952 changes.

Sections 5 and 409 deal with the organization and functions of the Commission. Section $5^{4}$ was amended by the $195^{2}$ Act so as to provide that the Commission should organize its staff into "integrated bureaus," by function, including in each bureau such legal, engineering, accounting, and administrative personnel as may be necessary. For example, the "Broadcast Bureau" would handle radio, television, and related matters; the "Common Carrier" Bureau would handle telephone, telegraph and other common-carrier activities. Even prior to the adoption of the r952 amendments, the Commission had, in fact, divided its staff into these functional bureaus; thus, the $195^{2}$ amendments merely codified this division. ${ }^{5}$ A new section 5 (c) was added to the Act; it created a "review staff," whose duties were to assist the Commission in cases of "adjudication which have been designated for hearing," by preparing for commission use a compilation and summary of facts material to the exceptions and replies filed after an initial decision; the "review staff" also prepares, upon specific direction, final and interlocutory opinions, memoranda or orders. The "review staff" is expressly forbidden from "recommending" a decision to the Commission in any matter; it is set entirely apart from every other department; its members cannot consult with any other staff members; nor can any other member of the staff perform "review staff" functions.

Section $409^{6}$ was amended to supplement this "separation of functions." It now requires that all adjudicatory hearings shall be conducted either by an examiner or by the full Commission, but not by one Commissioner. An initial decision must be prepared by the hearing officer, except in emergency circumstances. The examiner cannot consult any person, except on the record, on any fact or question of law in issue, even including another examiner; nor can he advise the Commission with regard to his initial decision. No persons who participated in the investigation or preparation of a given case, no member of the Office of the General Counsel, the Chief Engineer, or the Chief Accountant shall make any additional presentation in the case, except upon the record in open hearing. All of these provisions are directed towards separating with finality the prosecuting and judicial functions of the Commission.

Section $309^{7}$ of the Act was also extensively amended to make definite and certain the procedural steps involved in securing a license. The 1952 amendments were intended to set forth specifically "the procedural rights and remedies of those who oppose, as well as those who apply for, a new instrument of authorization."8 Section

\&66 STAT. 7I2, 47 U.S.C. \$ I55 (1952).

- Wall and Jacob, supra note 2, at 145 .

- 66 STAT. 721, 47 U.S.C. $\$ 409$ (1952).

766 STAT. 715, 47 U.S.C. $\$ 309$ (I952).

${ }^{8}$ Committee on Interstate and Foreign Commerce, supra note 3 , at 8. . 
309(b) now requires that before designation for hearing, the Commission must notify in writing the applicant and other known parties in interest as to why the grant cannot be made; the applicant can reply to this letter. If still unable to make the grant, the Commission shall designate the application for hearing and it must specify with "particularity" the matters in issue. Any "party in interest" is given the right to intervene in the proceeding. The hearing held thereafter shall be a "full" evidentiary hearing.

A new subsection, section 309 (c), established what is now referred to as the "protest" rule, whereby any grant made without hearing remains subject to "protest" or objection by any "party in interest" for a period of thirty days. If a "protest" is filed, it must set forth the facts showing "protestant" to be a "party in interest" and must specify with particularity the "facts, matters, and things relied upon" to show that the grant will not serve the public interest. If the Commission finds that the protest meets these requirements, it shall designate the application for hearing upon the issues set forth by the protestant, except where, after giving oral argument, the Commission finds no basis for setting aside the grant, even assuming the truth of the factual allegations in the protest. Pending final decision, the effectiveness of the grant is postponed, unless necessary to the maintenance of an existing service or unless the Commission affirmatively finds that the public interest requires that the grant remain in effect.

Section $3 \mathrm{xo}(\mathrm{b})^{9}$ of the Act, dealing with assignments and transfers of broadcast licenses, was amended so as to prohibit the so-called "Avco" procedure, whereby the Commission permitted any well-qualified bidder to apply for the frequency being sold, hence necessitating a hearing to determine which was the best-qualified buyer. The 1952 amendments expressly forbade this result. Here again, though, the "Avco" procedure had already been abandoned, prior to the adoption of this Act; ${ }^{10}$ the $195^{2}$ amendments resulted only in forbidding its reintroduction. Section $3^{12^{11}}$ was amended so as to give the Commission the power to issue "cease and desist" orders, after notice and hearing. Thus, an additional administrative sanction, short of revocation or failure to renew, was made available. Finally, the judicial review sections, sections 402 (a) and $402(b)^{12}$ were extensively revised so as to clarify existing law and make clear and certain rights on appeal. The court was also given the power to grant temporary relief and was given some supervisory power over Commission action after remand.

This brief summary of the major procedural revisions indicates the intent of Congress to clarify the procedural rights of litigants and to guarantee a fairer hearing. As indicated before, it is believed that the 1952 amendments have not done the job expected. However, any criticism of the 1952 amendments, and the results thereunder, must be tempered by one important observation. During this past five-

\footnotetext{
פ 66 STAT. 716, 47 U.S.C. $\$ 310$ (b) (1952).

${ }^{10}$ Committee on Interstate and Foreign Commerce, supra note 3 , at 9.

${ }^{11} 66$ STAT. 716, 47 U.S.C. $\$ 312$ (1952).

1266 STAT. 719, 47 U.S.C. $\$ 402$ (1952).
} 
year period, the Commission has been faced with a terrific workload. The major increase in workload has resulted from the processing of new television applications, which obviously would have strained any procedure, good or bad. Nevertheless, the 1952 amendments have contributed to the difficulties. The stringent prehearing procedures of section 309 (b), the hearing requirements of section 409 , the intervention requirements of section 309 (b), the protest provisions of section 309 (c), the separation of functions provisions of section $5(\mathrm{c})$-these and similar provisions enacted in 1952 certainly guarantee a full hearing in all conceivable adjudicatory proceedings. But with such procedures, substantial delay, expense, and occasional un. fairness have been the inevitable result.

Thirty-five percent of all broadcast applications are required to go through hearing. There is an average of two hearings each Commission workday. ${ }^{13}$ Some television cases have taken more than four years before final decision, from the time the applications were filed. In "protest" cases under section 309 (c), where the Act specifically directs the Commission to "expedite" consideration of the matters raised, hearings normally take more than a year. A lawyer today advises his client in a normal case likely to be designated for hearing that he should not expect final decision in less than two years from the filing of his application.

Is this substantial delay and expense, stemming in part from the 1952 procedural amendments, justified by the quality or fairness of the results? It is commonly believed that one principal advantage of administrative action is supposed to be its speed and flexibility of decision. It is perhaps better, from the point of view of the listening public, particularly in comparative hearings where a number of wellqualified applicants are competing, that there be a prompt result, rather than necessarily the most just result. If these administrative advantages of speed and dispatch are to be sacrificed, has this loss been offset by the high quality of the end product? Here, again, the answer would seem to be "No." And again the responsibility for the negative answer in some measure rests with the 1952 amendments, themselves. The "separation of functions" provisions have proved particularly troublesome (sections 5 and 409); the extensive procedural requirements, particularly the "protest" provisions, have contributed to a great deal of vacillation, poorly-reasoned opinions, and interminable litigation (section $309(\mathrm{c})$ ).

There is but one major criteria of effective administrative action left: have the I952 amendments contributed substantially towards fairer and more just decisions? It might well be argued that in the interest of absolute fairness to the private parties involved, the delay and loss of efficiency are worthwhile. During the hearings on the I952 amendments, Congress was impressed with the charges that applicants "have not always had the most equitable judicial treatment."14 Prior to I952, there had been considerable criticism of particular activities, practices, and excesses. But the system, as such, was not unfair. The $195^{2}$ amendments attempted to guarantee fair-

${ }^{13}$ FCC, Twenty-Second Ann. REP. 8 ( 1956 ).

${ }^{24}$ Committee on Interstate and Foreign Commerce, stipra note 3 , at 6. 
ness, however, by describing in some detail the exact procedures the Commision had to follow and by taking from the Commission certain areas of administrative discretion. This attempt to legislate administrative morality has not been successful. The limitation on discretion does not necessarily improve the integrity of the process or the ability of the administrators.

As will appear later, the "protest" provisions as originally enacted have placed the Commission in an administrative strait-jacket. The public's interest in receiving greater service has been sacrificed, through loss of discretion, to the purely private interest of competitors seeking delay and obstruction. This attempt to legislate "fairness" has only led to a greater "unfairness," with the public the principal loser.

So also the "separation of functions" provisions have not brought about any substantially fairer results. All the separation provisions do is to separate, in adjudicatory matters, the Commission from most of its staff. Granted that staff members might become sufficiently powerful or persuasive as to bring about an improper exercise of influence, it is still questionable whether staff influence, as such, is a significant or present danger to a fair hearing on the record.

The 1952 amendments have attempted to deal with one of the most difficult and delicate problems facing the administrative process-namely, how can the needs of the agency for consultation, advice, and information from all sources be accommodated to the need for a fair decision on the record in those situations where a record is required? The 1952 amendments dealing with internal separation have touched upon one minor aspect of this total problem. Influences and pressures are brought to bear in Commission proceedings. There is no question of that. ${ }^{15}$ Most of the pressures, however, originate from persons entirely outside the agency. The effectiveness of these pressures cannot, of course, be accurately evaluated. Whatever their effectiveness, and certainly there is some, they are contrary to the basic principle that in adjudicatory matters at least, the decision must be based solely on the record. More will be said about this later. But suffice it to say now, that where "separation of functions" is most needed-to defend against these pressures stemming from sources outside of the Commission-the 1952 amendments have had no applicability.

The foregoing summary has pointed out the major respects in which the Communications Act Amendments, I952, have not fulfilled the high hopes of their proponents. There hereafter follows a more detailed documentation to support the basic thesis that efficiency and expedition have been sacrificed, with no appreciable improvement in fairness to the parties.

\section{II}

\section{Separation of Functions}

The "separation of functions" provisions of sections $5(c)$ and 409 have already been briefly described in the introduction. The appropriate provisons are set forth

${ }^{15} \mathrm{Jaffe}$, The Scandal in TV Licensing, Harper's Magazine, Sept. 1957, p. 77. 
below. ${ }^{10}$ A mere reading of these provisions demonstrates the extensive attempt made by Congress to insulate the staff from the Commissioners, themselves, and to limit the activities of the various staff members who participate at one stage or another in the adjudicatory hearing process. The seven Commissioners and their personal professional assistants thus bear a tremendous burden. In practice, they simply cannot do an adequate job. The Commissioners are busy men. As of June 1957, more than $1,800,000$ radio authorizations were outstanding, including 774 television authorizations and 3,238 standard broadcast authorizations. During the fiscal year ending June 30 , I957, more than 500,000 applications were filed-ig00 applications were filed each day, as well as innumerable pleadings, petitions and letters. On June $3^{\circ}$, 1957, there were 360 hearing cases pending. ${ }^{17}$

The problems requiring the personal attention of the Commissioners vary from the most routine administrative matter to the most complex rule-making proceeding. For example, in the case of the subscription television rule-making proposal, 25,000 pleadings, letters, documents and cards were filed. ${ }^{18}$ Obviously, with this heavy workload, there is a need for flexibility in the use of available manpower. Yet, the "separation of functions" provisions have not permitted this needed flexibility in adjudicatory proceedings. Two glaring bottlenecks have developed-one with the

${ }^{10}$ Section $5(c)$ provides in pertinent part (66 STAT. 712, 47 U.S.C. $\$ 155$ (I952)):

The Commission shall establish a special staff of employees ... which shall consist of such legal, engineering, accounting and other personnel as the Commission deems necessary. The review staff shall be directly responsible to the Commission and shall not be made a part of any bureau or divisional organization of the Commission. ... [It] shall perform no duties or functions other than to assist the Commission, in cases of adjudication ... which have been designated for hearing, by preparing a summary. of the evidence presented at any such hearing, by preparing, after an initial decision but prior to oral argument, a compilation of the facts material to the exceptions and replies thereto ... and by preparing for the Commission ... without recommendations and in accordance with specific directions from the Commission ... memoranda, opinions, decisions, and orders. The Commission shall not permit any employee who is not a member of the review staff to perform the duties and functions which are to be performed by the review staff. ..."

Sec. 409 (c) provides in pertinent part (66 STAT. 72T, 47 U.S.C. $\$ 409$ (1952)):

"f 409 (c) (x) In any case of adjudication ... which has been designated for a hearing by the Commission, no examiner conducting or participating in the conduct of such hearing shall, except to the extent required for the disposition of ex parte matters as authorized by law, consult any person ... on any fact or question of law in issue, unless upon notice and opportunity for all parties to participate. ... No Examiner conducting or participating in the conduct of any such hearing shall advise or consult with the Commission ... or employee of the Commission ... with respect to the initial decision in the case or with respect to exceptions taken. ....

"§ 409 (c)(2) In any case of adjudication . . . which has been designated for a hearing by the Commission, no person who has participated in the presentation or preparation or preparation for presentation of such case before an examiner. ... and no member of the Office of the General Counsel, the Office of the Chief Engineer, or the Office of the Chief Accountant shall ... directly or indirectly make any additional presentation respecting such case, unless upon notice and opportunity for all parties to participate.

"s 409 (c) (3) No person or persons engaged in the performance of investigative or prosecuting functions for the Commission, or in any litigation before any court in any case arising under this Act, shall advise, consult, or participate in any case of adjudication ... which has been designated for a hearing by the Commission, except as a witness or counsel in public proceedings."

${ }^{17}$ FCC, Twenty-Throd Ann. Rep. I, 3, 4, 21, 25, I25 (1957).

${ }^{18}$ FCC, op. cit. stpra note $\mathrm{x} 3$, at 100 . 
Commissioners, themselves, since they must personally decide these various matters with little assistance, the other with the "review staff," or what has been officially designated "Office of Opinions and Review." This small and independent section has imposed upon it a tremendous paper workload. In every adjudicatory decision, large or small, interlocutory or final, a member of the "review staff" must thoroughly familiarize himself with all aspects of the case and write a complete and accurate summary of all relevant evidence and material points involved. Then he must write the final decision after instructions by the Commission.

It is believed that in matters as important and complex as the adjudicatory cases, the Commission should have available the best internal counseling and assistance possible from as many sources as possible, consistent with basic principles of administrative fairness as set forth in section five of the Administrative Procedure Act of 1946.19 As has been mentioned before "separation of functions" within the agency is simply one aspect of the general goal of guaranteeing in adjudicatory matters a decision based upon a record made in open hearing. The difficulty arises in accommodating this basic goal to the over-all needs, functions, and status of the independent regulatory agency. In the case of broadcasting, the Commission is dealing with a dynamic growth industry of tremendous potential. A television or radio franchise can be tremendously valuable. ${ }^{20}$ So also, the common carrier and industrial uses of radio, as yet in their infancy, already involve multi-million dollar investments. Both radio and television have an unequalled ability to bring entertainment, education, and information to the public. This potential for influence and financial gain has not been overlooked by the astute business, entertainment, and educational interests.

All of these interests are clamoring for a share of the spectrum. The pressures, therefore, upon the Commission are intense. In almost all cases, the pressures emanate from sources outside the Commission. These outside pressures exist whether or not the matter at issue concerns administrative processing, rule-making or adjudication. It is asking too much, in our present administrative scheme, to expect administrators to resist or ignore these pressures entirely. The Commission has administrative and rule-making functions in which interested parties are encouraged to confer and consult with the Commission so that it can better appreciate the needs and interests of the business it is regulating. Hence, the habit of direct consultation by interested parties is part of the process and is well-established. ${ }^{21}$

Also, the Commission is an agency of the Congress. Though an independent regulatory agency, it is still directly responsible for the implementation of congres-

${ }^{10} 60$ STAT. 239 (1946), 5 U.S.C. $\$ 1004$ (1952).

${ }^{20}$ During $\times 957$, Station WNEW (AM), New York, N. Y., sold for $\$ 5,160,800$, in 1955, Station WDTV (TV), Pittsburgh, Pa., sold for \$9,750,000. See FCC, op. cit. sttpra note 17 , at 123.

${ }^{21}$ See Van Curler Broadcasting Corp. v. United States, 236 F.2d 727, 73I (D.C. Cir. I956), where the Court of Appeals condoned the practice of consulting with the Commission, ex parte, so long as not connected to specific docketed rule-making proceedings. Even in adjuclicatory comparative hearings, the process of judgment and selection rests on informed discretion and experience, not readily apparent from a mere study of the record. See Pinellas Broadcasting Co. y. FCC, 230 F.2d 204, 206 (D.C. Cir. r956). 
sional policy. At any time, Congress can limit appropriations, thus limiting personnel and activities, or enact substantive legislation dictating policy and procedures. Because Congress is charged with the responsibility of appropriating money for these agencies and supervising their activities, individual congressmen are besieged with requests and demands for the adoption of a certain policy, or the deletion of certain powers, or the grant of a particular permit or privilege. As might be expected, congressmen have been quick to respond to the pleas of their constituents, as well as to recognize an occasional political "issue" upon which they can capitalize. There have been interminable congressional investigations of the Commission. ${ }^{22}$ In 1956 , there were at least I4 separate congressional committees or subcommittees probing the affairs of the Commission. ${ }^{23}$ Even where matters were pending at the Commission in formal docketed proceedings, congressional committees or individual congressmen held hearings and issued reports urging the Commission to adopt a certain, often highly controversial, solution. ${ }^{24}$

Other influences brought to bear are not so open or brazen. But they do, in fact, occur, and they occur outside the formal record. The habit of consultation by congressmen, members of the executive departments and interested parties is, thus, wellestablished, if not inherent in the system. Obviously, this habit of consultation inevitably is sometimes brought to bear in specific adjudicatory proceedings. The habit of consultation, once established, is not easily broken.

The 1952 amendments have not changed this situation. They have insulated the Commission from its own staff and established elaborate hearing procedures, but the amendments have not insulated the Commission in adjudicatory proceedings from Congress, the executive, or the public. Lack of fairness-if by what we mean pressures brought to bear dehors the record-still persists. Justification for a serious reappraisal of our system is certainly present today, but it is not the purpose of this article to do more than state the facts as they exist. The facts are that "separation of functions" as found in the 1952 amendments do not reach the source of the most serious threats to a decision based on the record. Yet, the amendments do result in a serious loss of administrative flexibility, efficiency, and expedition.

The basic principles of separation of functions must be observed in any fair administrative adjudicatory process. The investigating and prosecuting functions of the Commission should be entirely separated from the decisional processes. To this extent, a separation of personnel and departments is both necessary and desirable.

${ }^{29}$ The Commission estimates that in the fiscal year 1956 , it devoted $3 \frac{1}{2}$ man-years in preparation for and attendance at congressional hearings. See FCC, op. cit. supra note 13 , at 7-8.

${ }_{23}$ Broadcasting-Telecasting Magazine, December 31, 1956, p. 42; id., July 30, x956, p. 46.

34 For example, while a final television decision was pending, word spread that a subsidiary of National Airlines would be favored; three senators wrote the Commission raising policy questions regarding propriety of grant to a certified airline. Broadcasting-Telecasting Magazine, Jan. 28, 1957, p. 50. And in the summer of 1956, while highly controversial rule-making proceedings were pending affecting specific cases in thirteen markets, an Interim Report was issued by a majority of the Senate Committee on Interstate and Foreign Commerce, urging the adoption of a particular solution. See Committee on Interstate and Foreign Commerce, Interim Report, The Television Inquiry, S. Rep. No. 2769, 84th Cong., 2d Sess. 8-1 I (1956). 
The examiners must be independent and must function purely as judges. Actually, this separation has been accomplished at the Commission without the benefit of the I952 amendments. The Administrative Procedure $\mathrm{Act}^{25}$ helps to guarantee this result. A separate "Office of Hearing Examiners" is established. The Commission is now divided into functional bureaus, one of which is the "Broadcast Bureau." Its responsibility is to process broadcast applications, check complaints, investigate violations, draft proposed broadcast rules and regulations, and, finally, to participate as a "party" in any formal hearings designated by the Commission. The Broadcast Bureau may be considered an administrative "district attorney's office." On the other hand, the General Counsel's Office, the Chief Engineer, and the Office of Opinions and Review are entirely separate from the Broadcast Bureau, and they have no prosecuting functions at all. Thus, there is an effective separation of functions, organizationally speaking, without regard to the detailed and specific requirements of the 1952 amendments.

Fortunately, efforts are being made by the Commission and others, looking towards a re-evaluation of the internal separation of functions provisions as they now exist. Legislative proposals are being prepared which will permit the Commission greater discretion to consult with key staff officers when these persons are not engaged in investigating or prosecuting functions. ${ }^{26}$ It is believed that legislative approval of these changes is in order. After all, a sense of "judiciousness" and basic integrity cannot be legislated. A really effective "separation of functions" will result from acceptance of basic principles of fairness, leaving the detailed implementation to informed and honest administrators.

\section{III}

\section{Section 309 (c) "Protest"}

None of the 1952 amendments have caused so much difficulty and delay and so much dissatisfaction as the "protest" provisions of section 309 (c). As originally enacted in 1952 , section 309 (c) of the Act reads as follows: ${ }^{27}$

(c) When any instrument of authorization is granted by the Commission without a hearing as provided in subsection (a) hereof, such grant shall remain subject to protest as hereinafter provided for a period of thirty days. During such thirty-day period any party in interest may file a protest under oath directed to such grant and request a hearing on said application so granted. Any protest so filed shall contain such allegations of fact as will show the protestant to be a party in interest and shall specify with particularity the facts, matters and things relied upon, but shall not include issues or allegations phrased generally. The Commission shall within fifteen days from the date of the filing of such protest, enter findings as to whether such protest meets the foregoing requirements and if it so finds the application involved shall be set for hearing upon the issues set forth in said protest, together with such further specific issues, if any, as may be prescribed by the

${ }^{25} 60$ SraT. $237-44$ ( 1946 ), 5 U.S.C. $\$ \$$ I00r-r I (I952).

${ }^{28} \mathrm{FCC}$, op. cit, supra note I3, at 24; id., TwentY-First ANn. Rep. 18 (1955).

${ }^{27} 66$ STAT. 7r5, 47 U.S.C. $\$ 309$ (c) (1952). The 1952 amendments gave the Commission only I5 days to act on a protest. This was extended to 30 days in 1954. 68 STAT. 35 (1954), 47 U.S.C. $\$$ 3ogc (Supp. III, 1956). 
Commission. In any hearing subsequently held upon such application all issues specified by the Commission shall be tried in the same manner provided in subsection (b) hereof, but with respect to all issues set forth in the protest and not specifically adopted by the Commission, both the burden of proceeding with the introduction of evidence and the burden of proof shall be upon the protestant. The hearing and determination of cases arising under this subsection shall be expedited by the Commission and pending hearing and decision the effective date of the Commission's action to which protest is made shall be postponed to the effective date of the Commission's decision after hearing, unless the authorization involved is necessary to the maintenance or conduct of an existing service, in which event the Commission shall authorize the applicant to utilize the facilities or authorization in question pending the Commission's decision after hearing.

This was a highly controversial section, even when placed in the 1952 law. Legislative history is replete with statements by official spokesmen for the Commission that protests by persons with an economic interest will burden the Commission's processes and delay the advent of new radio and television service. ${ }^{28}$ Yet, still Congress passed the new bill.

It is important, therefore, to determine what this new section was originally intended to accomplish. This subsection applies only to grants made without hearing, pursuant to section 309(a). Any objections made by outside parties to the grant of a proposed application were considered by the Commission at the time it made its grant. History had shown that in situations like this, even though the Commission's Rules prior to $195^{2}$ permitted the filing of a protest, and even though section 405 of the Act permitted reconsideration and rehearing, in fact the Commission was very lax and dilatory in its consideration of the objections by outsiders. Considerable periods of time would pass before the objections were considered; in the meantime, the station whose authorization was being protested had completed construction and was on the air. This, of course, vitiated the effectiveness of the objections. Furthermore, acceptance or not of the objections rested solely within the discretion of the Commission. Its disposition was usually by summary order, with almost no discussion of the errors urged.

The new section 309 (c) was designed to make "definite and certain the procedural rights and remedies" of objectors to the grants, as well as the applicants themselves. The section gave to any person who has the right to challenge the propriety of the grant by appeal to the courts the preliminary right to complain first to the agency, and his complaint had to be acted upon within 30 days. The section provided that if a person shows himself to be a "party in interest" and if he set forth his objections "with particularity," then he was entitled not only to a hearing on his objections, but also to a stay of the effectiveness of the grant, except in those cases where the grant was necessary to the "maintenance or conduct of an existing service."

\footnotetext{
${ }^{28}$ See, e.g., Hearings before a Subcommittee of the Senate Committee on Interstate and Foreign Commerce on S. 1973, 81st Cong., Ist Sess. 17, 34 (1949); Hearings before the House Committee on Interstate and Foreign Commerce on $S .658,82 \mathrm{~d}$ Cong., Ist Sess. 69-70 (r95r); Committee on Interstate and Forcign Commerce, supra note 3 , at 8 .
} 
In most cases where the protest was granted, the new authorization was stopped dead in its tracks. This was so, regardless of the likelihood of eventual success on the merits, regardless of the need for the new service, and regardless of the motives or purpose of the protesting party. The party most likely to suffer economic injury was the direct competitor of the new station in the market or area involved. It becomes obvious that a tremendously potent weapon was available to existing stations seeking to preserve the status quo, to limit competition, or at least to delay competition for as long as possible. Thus, section 309 (c), almost as if by intent, became a tool for existing competitors seeking to prevent or delay new competition.

To appreciate the significance of this, it is necessary to understand a basic principle of communications law as set forth in the landmark case, FCC v. Sanders Bros. Radio Station. ${ }^{29}$ In the Sanders decision, the sole existing station in the community objected to the grant of a new second station, claiming there was insufficient advertising revenue to support both stations. The Commission refused to consider this factor, holding that economic injury to an existing station was not grounds for refusing to license a newcomer. The Commission also argued that since the existing station could not assert economic injury to itself as a grounds for denying a license, it had no standing to appeal stemming from this economic injury. Absence of right, it was argued, implies absence of remedy.

The Supreme Court established two principles in its decision. First, the Court held that resulting economic injury to a rival station "is not in and of itself, and apart from considerations of public convenience, interest, or necessity, an element the petitioner must weigh and as to which it must make findings in passing on an application for a broadcast license."30 Second, despite the Commission's claim that "absence of right implies absence of remedy," the Court held that the Act still confers upon persons "likely to be financially injured" by the grant the right to prosecute an appeal.

Thus, in communications law, there is the curious but well-established principle that an existing station likely to be economically injured has the right to object to a new grant; yet, the existing station cannot assert its own economic injury as a substantive reason for denying the new grant. It must find other reasons why the grant is improper. It is this limited principle of "standing" which has been the foundation for almost every protest filed during the past five years. Two principal difficulties have developed. In the first place, competitors who obviously had "standing" began to utilize section 309 (c) as a delaying device, upon the flimsiest pretext and without any real substance to their case. Second, the Commission, itself, attempting to defend against this type of flimsy protest, went way too far in frustrating the procedural remedies available under section 309 (c). Needless to say, its efforts caused only further litigation, delay, expense, and frustration.

There are four areas where the Commission's overzealous attempts to limit the protest provisions have caused serious problems:
${ }^{29} 309$ U.S. 470 (1940).
${ }^{30} 1 d$. at 473 . 
(I) Defining who are "parties in interest, entitled to 'protest' ";

(2) Defining the degree of "particularity and specificity" necessary to state, in the protest, an adequate showing of irregularity or illegality;

(3) Defining the nature and extent of the protest hearing; and

(4) Determining whether to issue a "stay" of the grant where the protest is set for hearing.

The most troublesome issue has been that of defining who is a "party in interest." Legislative history was presumably very clear on this, for the senate report said: $:^{\text {Ix }}$

'( $\mathrm{P})$ arties in interest' because of electrical interference are fixed and defined by the Supreme Court decision in the KOA case ( $3 \times 9$ U.S. 239) and the Commission's rules and regulations; 'parties in interest' from an economic standpoint are defined by the Supreme Court decision in the Sanders case (309 U.S. 470).

Significantly, section 309 (c) is not needed where the "protestant" bases his claim upon objectionable interference. The Supreme Court in FCC v. NBC $(K O A),{ }^{32}$ had already ruled that if objectionable interference is caused to an existing station, the station's license is, in effect, being modified and a hearing is necessary. The present section $3^{1} 6$ of the Act expressly covers modification cases and provides much more effective procedural protections for a station whose license is being modified than does section 309 (c).$^{33}$ Therefore, the only important application of section 309 (c) is to cases where the protestant's claim to standing is based on economic injury.

The Commission decided in the beginning that one effective way to cut down the applicability of the protest provisions was simply to define narrowly the class of persons entitled to invoke that section. Indeed, one of the very earliest decisions decided that an existing radio station could not protest the grant of a new television station, since they were not in direct competition. ${ }^{34}$ The loser immediately appealed; while the appeal was pending, the Commission reversed itself and agreed to let the protest lie. ${ }^{35}$

Another early case involved two stations $33^{\circ}$ miles apart. Obviously, the stations were not competitors, but the grant of improved facilities to one caused interference to a large part of the other's service area, though outside the area entitled to protection. The station losing service claimed that it sold advertising based on the tremendous area it covered. Thus, the loss of service area would make the station less attractive to advertisers. The Commission refused to find standing on these facts. ${ }^{36}$ However, on appeal, the court of appeals held that the station losing service was a party in interest to the grant and that there was a satisfactory showing of "a likelihood of injury" within a meaning of the Sanders case. ${ }^{37}$

\footnotetext{
${ }^{81}$ Committee on Interstate and Foreign Commerce, supra note 3, at 8.

${ }_{32}^{319}$ U.S. 239 (1943). $\quad{ }^{32} 66$ STAT. 7x7, 47 U.S.C. $\$ 316$ (1952).

36 Versluis Radio and Television, 9 PIKe \& Fischer Radio Reg. 104 (I953) [hereinafter cited as

${ }^{35} 9$ R.R. 102 (1953). Other cases reaffirmed this. See, e.g., T. E. Allen \& Sons, 9 R.R. 197 (1953);

Salinas Broadcasting Corp., 9 R.R. I92 (1953).

${ }^{30}$ Alvarado Broadcasting Co. (KOAT), xo R.R. $382 a$ (1954).

${ }^{37}$ Metropolitan Television Co. v. United States, 221 F.2d 879 (D.C. Cir. x955).
} "R.R."] 
The Commission has permitted protests by newspapers to the grant of a new television station ${ }^{38}$ and to the renewal of a standard broadcast license, ${ }^{39}$ on the theory that both newspapers and radio or television are competing for the local advertising dollar. The Commission was not so liberal in the case of W. Wright Esch. ${ }^{40}$ In this case, the protestants objected to the approval of an assignment of license, alleging that they had an option agreement with the licensee to purchase the radio station but that instead the licensee sold the station to a third party. The protestants stated that they were suing the licensee in the state courts to enforce the option contract, but that if the Commission approved the assignment, their contractual rights would be impaired. The Commission held that the protestants had no standing. On appeal, the court of appeals reversed, finding that this contractual right gave protestants a sufficient "interest" in the assignment so as to qualify them as "parties in interest."

The Commission was not to be outdone, though. The state trial court at a later date decided that the option contract was not enforceable; the protestants appealed this decision to a higher state court. While the appeal was pending, the parties to the transfer filed a petition for reconsideration before the Commission. The Commission thereupon dismissed the protest. ${ }^{42}$ The Commission held that since the claim to standing rested on the alleged contractual rights which the trial court had now found to be unenforceable, the protestants no longer had standing. It would seem that since an appeal from the trial court was pending, the Commission's action is unduly restrictive. ${ }^{43}$

The Commission has consistently held that mere applicants do not have standing to protest the grant of another pending application. ${ }^{44}$ These decisions follow an earlier court of appeals decision in Mansfield Journal Company v. FCC.45 On occasion, however, the court of appeals has approved objections in the nature of a protest brought by applicants. For example, in McClatchy Broadcasting Co. v. FCC, ${ }^{40}$ on rehearing, the court permitted an unsuccessful comparative applicant in a television case, while its appeal was pending, to "protest" a modification of construction permit of the successful applicant in the comparative case. The court thought the grant of the modification application substantially changed the successful applicant's original proposal, thereby prejudicing the unsuccessful applicant.

One test the Commission has used, with varying success, to limit the class of persons entitled to be considered "parties in interest" is its "new injury" test, i.e., the Commission requires that the protestant show likelihood of economic injury stemming solely and directly from the particular action being protested. For example, where an applicant files an application for additional time to construct its station, the

${ }^{38}$ Ohio Valley Broadcasting Corp., Io R.R. 452 (1954).

${ }^{30}$ Richland (WMAN), I3 R.R. II3 (1955). ${ }^{40} 12$ R.R. 12506 (1955).

${ }^{41}$ Granik v. FCC, 234 F.2d 682 (D.C. Cir. 1956).

${ }^{42}$ W. Wright Esch, 14 R.R. I165 (1957).

${ }^{43}$ The protestants have appealed the decision. Granik v. FCC, Case Nus. 13730 and 13731.

"4 Ians Lansdown (KRKS), I4 R.R. 488 (1956); Central City-Greenville Broadcasting Co. (WNTA), II R.R. 484 (I954).

${ }^{45}{ }_{173}$ F.2d 646 (D.C. Cir. 1949). ${ }^{40}{ }_{13}$ R.R. 2072 (1956), 
Commission has held that no protest will lie. ${ }^{47}$ It claims that Congress did not intend to allow protests to later Commission actions which do not change the competitive situation from that present at the time of the original grant. ${ }^{48}$ There may be some justification for this, since an application for extension of time does not change in a material way the actual proposals which were approved at the time of the original grant. But what about the situation where the application for modification of permit actually changes substantially some of the legal, technical, financial, or other aspects of the operation?

This problem arose in the case of Midwest Television. ${ }^{49}$ Here, the applicant proposed to change its transmitter site so as to place a substantially better technica! service over protestant's city. The protestant objected to this move, claiming that this would cause more direct competition with its own station than under the prior grant. Despite some doubts, the Commission found that the protestant was a party in interest because the move in transmitter location substantially changed the com. petitive situation. This decision seems clearly correct, since, in effect, protestant was being faced with a new competitor. ${ }^{50}$

Yet, in other cases, where the factual situations are hard to distinguish, the Commission has refused to find a new competitive injury and has denied standing. ${ }^{51}$ In Spartan Radiocasting Company, ${ }^{52}$ the applicant proposed a new location for its transmitter 25 miles away from its original site and five miles from the protestant's city. The protestant claimed not only would this new location increase the competition between the stations, but also the new transmitter site would enable the applicant to obtain a network affliation not otherwise available to it. The Commission held that protestant had no standing because there was no fundamental change in the basic competitive situation, it being speculative as to whether the move would cause new injury from that the protestants would have suffered under the original grant. The protestants appealed this decision, claiming that a showing of "new injury" was not necessary under section 309 (c), and also, even if it was necessary, a sufficient showing had been made. The court of appeals did not decide the validity of the Commission's new injury test. It did decide, however, that a sufficient showing of new injury had been made on the facts, namely, the protestants' allegation that only by moving to the new location could the applicant obtain a network affiliation..$^{53}$

The Commission also tried to apply the "new injury" test to cases involving the sale of broadcast stations, so as to deny standing. In the case of Leo Howard, ${ }^{54}$ a

${ }^{47}$ Channel 16 of Rhode Island, ro R.R. 377 (1954).

${ }^{48}$ For example, $\$ 31 \dot{9}$ (c) of the Act expressly exempts license grants from protests, 66 STAT. 718, 47 U.S.C. $\$ 319(c)$ (1952), because a license follows almost automatically from the grant of an original construction permit, which is subject to protest. Committee on Interstate and Foreign Commerce, supra note 2 , at II.

${ }^{10} 9$ R.R. 6 II (1953).

${ }^{50}$ Cf. Gulf Television Co., II R.R. 460 (1954); Van Curler Broadcasting Corp., II R.R. 215 (1954).

${ }^{61}$ See, e.g., Southwestern Publishing Co., II R.R. 466 (1954).

${ }^{52}$ Io R.R. 281,287 (1954).

${ }^{88}$ Greenville Television Co. v. FCC, 221 F.2d 870 (D.C. Cir. I955).

8 9.R. 359 (1953). 
radio station protested the assignment of a construction permit of its competitor. The new station had not, in fact, been built; a construction permit only was being assigned. The Commission concluded that since the protestant had not protested the original grant to the assignor, it could not protest the assignment since no new injury would be caused. The court of appeals, however, rejected this argument. ${ }^{55}$ The court held that the Act expressly permitted the protest of assignments and transfers. As long as the station protesting was an existing competitor, its rights to protest did not depend on whether new or different injury would be caused.

The court, however, did not expressly reject the "new injury" test. Later, the Commission once again applied its "new injury" test in a transfer case, James Robert Meachem. ${ }^{56}$ Here, a television permittee protested the transfer of its competitor's radio and television station to a large corporation. The Commission held that the protestant had no standing. It attempted to distinguish the Camden decision by claiming that Camden dealt with the transfer of a station which was not yet on the air; thus, the protestant would be suffering a new injury when the assigned station-took the air. This attempted distinction is clearly erroneous, since the court of appeals decision was simply based on the proposition that the Act expressly permits protests of transfers and assignments. Nevertheless, the Meachem case was never appealed and, thus, it still stands as precedent.

It is believed that when the "new injury" test is presented squarely to the court, it will be rejected. Any authorization results in a permission to construct or operate. From a purely technical point of view, "new injury" is established each time the applicant actually commences construction or operation under the new authorization. Thus, the "new injury" test is not really helpful. A more appropriate analysis would look to the nature of the objections raised. If the objections should have been raised, or could have been raised, within 30 days from the grant of the original construction permit, then any rights to raise such objections expire with the passage of the 30-day protest period. However, where the objections raised by the protestant concern only the actual new authorization, or concern facts only coming to protestant's attention at the time of new grant, the protestant could not have made those objections known prior to the actual new application in issue. In those cases the protest should lie so long as the protestant meets the normal tests of a "party in interest." 57

From the foregoing, it can be seen that in most cases, the Commission has attempted to restrict the applicability of the "party in interest" concept, whereas the Court of Appeals for the District of Columbia has developed a rather liberal and pragmatic test. It is enough that a potential for economic injury is present without

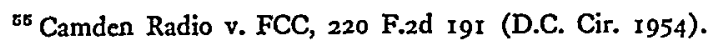

${ }^{88}{ }_{12}$ R.R. I427'( ${ }^{5955)}$.

${ }^{57}$ Sometimes mecting the test of a "party in interest" involves disputed issues of fact. One solution adopted by the Commission has been to grant the protest, but include the issue of "standing" as one of the hearing issues. Prairie Broadcasting Co. (WPRE), 14 R.R. $520(\mathrm{~g})$ (1956). But cl. United Broadcasting Co. (KEEN), 13 R.R. 1309 (1956); Q Broadcasting Co., 14 R.R. 1168 (1957). 
regard to the express details of how the injury will occur or the degree to which it will occur. This view by the court seems eminently proper in light of the clear language of the section and the intention of Congress. Despite the evils of the protest section, the Commission's attempt to limit its applicability is not the solution.

The Commission has attempted in still another way to limit the effectiveness of section 309 (c). The section expressly requires that the protestant "specify with particularity the facts, matters, and things relied upon" to show that the grant would not serve the public interest. The Commission has required protestants to plead their entire case in considerable detail. As might be expected, this attempt to impose a strict standard of particularity has led the Commission into the "never-never land" of pleading, reminiscent of the early common law problems of defining an adequate cause of action.

In a very early case under the new section 309 (c), the Commission set forth the following test: ${ }^{68}$

A protestant must do something more than set forth in his protests vague, non-specific, conclusionary arguments; he must allege those facts upon which his conclusion as to the impropriety of the Commission's grant without a hearing are predicated. . ... they (the facts alleged) must be concrete, basic facts.

With this general statement, one cannot quarrel. Certainly, if the protestant claims that a particular grant should not stand, then he should be able to set forth why this is so, in sufficient detail to demonstrate the substantial nature of his charges. The difficulty has been applying this general test to the particular cases. ${ }^{59}$ The Commission, itself, has vacillated back and forth.

For example, several years after having made the statement quoted above, and after having denied a number of protests which were presumably defective by that test, the Commission, in Coos County Broadcasters, ${ }^{60}$ permitted a protest to stand even though it conceded that the matters alleged in the protest were entirely vague and general. The Commission decided that the protest was not frivolous or sham and that there was a "not insubstantial possibility" that a hearing might reveal merit to the protestant's claim. This relaxation of the standard may have reflected, however, a deference to the court of appeals, for, as might be expected, the court has stepped into this matter on several occasions.

In Federal Broadcasting System, Inc. v. FCC, ${ }^{61}$ the court set forth what is now the accepted test of particularity:

[The protestant must] show in some detail the factual basis of his grievances. Generalized objections are obviously insufficient under the statute without some specification of events and circumstances. But neither are we to measure the requirement of Section $309(\mathrm{c})$ by the technicalities of pleading formerly applicable in civil litigation. What is required is (1953).

${ }^{68}$ T. E. Allen and Sons, 9 R.R. 590a, 594 (1953). See also Patroon Broadcasting Co., 9 R.R. 638

${ }_{50}$ See e.g., Hyman Rosenblum, II R.R. 826 (1954).

${ }^{13}{ }_{13}$ R.R. 625 (I956).

${ }^{01} 225$ F.2d 560, 563 (D.C. Cir. I955), cert. denied, 350 U.S. 923 (1955). 
merely an articulated statement of some fact or situation which would tend to show, if established at a hearing, that the grant of the license contravened public interest. . . . [Footnotes omitted.]

In a later case, Federal Broadcasting System, Inc. v. FCC, ${ }^{62}$ the court apparently even went further in permitting the protest to stand, despite the lack of particularity. The court said:

Only if it is clear from the face of the protest, taking all the protestant's allegations as true, that there is no real merit in protestant's position or substantial possibility that a hearing will reveal merit, should the protest be rejected without a hearing.

Despite the liberal judicial interpretation, the Commission continues to insist that there must be allegations of basic fact not based on surmise or speculation. ${ }^{03}$ This insistence upon a detailed showing of basic facts will continue to cause doubt and difficulty in future cases.

Still another fundamental problem has arisen in the administration of section 309 (c), namely, that of defining the nature or scope of the hearing to be granted where the Commission grants the protest. The Act itself, as enacted in 1952, gave no particular insight into this problem. As expected, from the very beginning, the Commission tried to limit the scope of the hearing. In T.E. Allen and Sons, ${ }^{04}$ the Commission ordered an oral argument en banc only. The Commission pointed out that there were no disputed issues of fact and concluded that oral argument suffices where questions of law and policy only are involved.

In Ohio Valley Broadcasting Corp. ${ }^{65}$ this principle was extended substantially. In that case, the Commission also permitted oral argument only. However, not only were questions of law and policy involved, but also, one issue, that of concentration of control, concerned facts about which the parties were in disagreement. The Commission said it would assume the truth of the facts alleged by protestant as if on demurrer. During this same period of time, the Commission became plagued with the so-called "economic injury protests," namely, protests filed by existing stations claiming that their particular market could not support a new station and that this financial inability of the market to support the newcomer was itself a reason for denying the grant. When this problem first came up, the Commission decided that oral argument only would suffice because this question involved a legal interpretation of the Sanders case, with factual allegations of secondary significance only. ${ }^{\circ B}$

However, the court of appeals in the case of Clarksburg Publishing Co. v. FCC, ${ }^{\text {,7 }}$ brought an end to this type of summary oral argument, as if on demurrer. The ${ }^{62} 23$ F.2d 246, 250 (D.C. Cir. 1956).

${ }^{03}$ See, e.g., WMIE-TV, II R.R. 1091 (1955); Richland (WMAN), I3 R.R. II3 (1955); Lebanon Broadcasting Co., 13 R.R. 388a (1956).

os Supra note 58 , at 594a.

${ }^{60}$ Io R.R. 500 (1954).

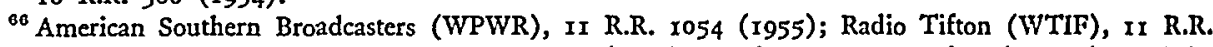
I167 (1955); Iredell Broadcasting Co., 12 R.R. 573 (1955); Southeastern Enterprises (WCLE), I2 R.R. 578 (1955).

${ }^{87} 225$ F.2d 5 II (D.C. Cir. 1955). 
Clarksburg case was an appeal from the earlier Ohio Valley case. This case involved problems concerning the Multiple Ownership Rules, concentration of control and diversification of the media of communication, and policies regarding the settlement of comparative cases. The Commission had permitted oral argument only on these matters. The court squarely held that the denial "rested on a seriously inadequate record." In a very sharp and critical opinion, the Commission was severely criticized for its handling of these protest cases, the court stating, "however unwittingly, the Commission seems to have assumed the defense of its grant, rather than the public interest, as its primary role in the proceedings." ${ }^{\text {"60 }}$ Section 309 (c), according to the court, contemplates an evidentiary hearing where there are unresolved factual issues, and more important, the Commission's inquiry should not be limited to the facts alleged in the protest where the Commission has reason to believe that a full evidentiary hearing may develop other relevant information not possessed by the protestant. $^{70}$ Faced with the strong language of the court in the Clarksburg decision, the Commission reversed its field and decided that the demurrer-type approach was inappropriate. It first ordered full evidentiary hearings in the economic-injury protests, finding that the legal and policy questions involved could best be determined after factual evidence was fully adduced. ${ }^{71}$ It took an amendment to section 309 (c), however, to bring any real clarity into the law on this point.

By 1955, the public, the bar, and the Commission were becoming totally dissatisfied with the harshness and unfairness of the protest section. In the summer of 1955 , the Commission sent to Congress a proposed amendment to section 309(c). In the letter to the Congress recommending a change in the Act, the then Chairman George C. McConnaughey stated $:^{72}$

The objective of the proposed legislation is to clarify the so-called "protest rule" contained in Section 309 (c) which was incorporated into the Communications Act by the Communications Act Amendments, I952, 66 Stat. 7 II so as to obviate the use of the new procedure as a device for delaying radio stations grants which are in the public interest, while at the same time retaining the rules' primary objective of providing interested parties with a means by which they may bring to the Commission's attention bona fide questions concerning grants made without hearing.

There are three principal means by which the new amendment improved the I952 law. First, the new amendment eliminates the necessity for holding full evidentiary hearings where the facts, even if proved, would not constitute grounds for setting aside the grant; the Commission now has the express power to treat protests, where appropriate, as if on demurrer, granting oral argument only. Second,

${ }^{08} 225$ F.2d at $5 \times 3$.

${ }^{00} \mathrm{Id}$. at $5 \mathrm{r} 5$.

${ }^{70}$ Even if a totally new basis for denying a grant arises other than that stated in the protest, the Commission must refuse to reinstate the grant. Hall v. FCC, 237 F.2d 567 (D.C. Cir. I956).

${ }^{71}$ Radio Tifton (WTIF), 12 R.R. 675 (1955).

II R.R. If I0:1100 (1955). Commissioner John C. Doerfer, the present Chairman, attached separate views requesting that the section be repealed entirely, claiming it "accomplishes no useful purpose." Ibid. 
the Commission was given some discretion to keep in effect the authorization being protested where the Commission finds that "the public interest requires that the grant remain in effect." Third, the new bill gives authority to the Commission to redraft or rephrase issues urged by the protestant. The bill passed the House and the Senate and became law January $20,195^{6.73}$

In some cases, the new law has been a great improvement. It has been helpful in those cases where an oral argument suffices to develop all relevant matters. The Commission commonly now uses this quick hearing rather than the full evidentiary hearing. ${ }^{74}$ The new section has also been helpful in many cases of initial licensing. Under the old provision, a competitor could invoke the mandatory stay provision so as to delay new competition, the only exception being where the grant was necessary to the maintenance of an existing service. ${ }^{75}$ This, however, was a rare situation.

Now the Commission has the power to permit the grant being protested to remain in effect if it finds affirmatively that the public interest requires it. For example, in Coos County Broadcasters, ${ }^{76}$ the Commission refused to stay the grant of a third station in the market, though granting the protest. It refused a stay, because the grantee proposed to operate the first independent station in the market, and also because a study of the allegations in the protest indicated that there was little likelihood that the protestants would prevail on the merits of their protest. Without their stay, the protestants immediately dismissed their protest, since they could no longer delay the new service; the grantee got on with the business of providing a needed service to this community at a much earlier date than would have been possible under the old act. In other words, where a new authorization is involved and where it will bring a needed service to the community, there is a good possibility that the stay will not issue. ${ }^{77}$ If it cannot obtain a stay, the existing station is less likely to continue the protest hearing. In any event, at least the Commission now has some discretion.

The major problem remaining in so far as stays are concerned, is whether transfer and assignment grants will be stayed upon protest. Certainly, it will prove difficult to avoid the stay upon the grant of a protest. After all, the transferor or assignor has been operating the station; except upon a most unusual showing, it can presumably continue to operate. Therefore, it is difficult for the Commission to find a compelling reason why the public needs the service from the transferee as opposed to service from the transferor. In some cases, it has been done; $;^{78}$ but in most cases, the stay has issued. ${ }^{79}$ Thus, in the typical assignment or transfer case, the new

${ }^{73} 70$ STAT. 3,47 U.S.C. $\$ 309$ (c) (Supp. IV, 1957).

74 See, e.g., Kaiser Hawaiian Village Radio (KHVH), 15 R.R. 76 (1957).

${ }^{75}$ Van Curler Broadcasting Corp. v. FCC, 225 F.2d 23 (D.C. Cir. 1955).

${ }^{70} 13$ R.R. 626 (1956).

${ }^{77}$ See, e.g., Wrather-Alvarez Broadcasting, 13 R.R. 754 (1956). If there is already adequate service to the area, then, of course, the stay will issue. Kaiser Hawaiian Village Radio (KHVH), 15 R.R. 76 (1957):

${ }_{78}$ O. R. Mitchell Motors, 14 R.R. 472d (1956); W. Wright Esch, I4 R.R. 47I (1956).

${ }^{70}$ William E. Walker, I4 R.R. 526 (1956). A real nightmare has occurred in the case of Good Music Station, I4 R.R. 512 (1956), where the Commission changed its mind several times about the stay, and Protestants were forced to go to court three times to protect their rights to the stay. Smith v. FCC, 247 F.2d 100 (D.C. Cir. 1957). 
section 309 (c) has not been much help in preventing the filing of meritless protests.

The Commission continues to have trouble in finding clear and simple tests to apply to protest proceedings. The constant changes in Commission position and the frequent resort to the courts certainly does not lead to expeditious and effective administration. Therefore, it is believed that further amendments to section 309(c) are in order. As Commissioner Doerfer said in an address before the Broadcast Advertising Club in Chicago, on October 29, $195^{6:}$

... today at least $30 \%$ of the time of our Examiners and our Office of Opinions and Review, and at least $30 \%$ of the time of the Commissioners is spent in deciding protest cases. Those, under the law, must be expedited. In most of them, the protestant has no other objective than to delay the implementation of a broadcasting service. These people love freedom of competition a good deal less than they love freedom from competition. Nonetheless, a thorough study of these hobbling procedural laws will convince fair-minded persons that much of the delay in the FCC is not the fault of the Commission.

Bills are now pending in Congress which would repeal section 309 (c) entirely. ${ }^{80}$ Perhaps such a drastic measure is not necessary, but at least a much more thorough amendment is necessary than that passed in 1956 . Matters of the public interest are primarily the responsibility of the Commission, not mere "private attorney generals" whose principal interest is to prevent competition with their own stations. Any interested party should have the right to call to the attention of the Commission errors of law or reasons why certain grants should not be made. The Commission should act promptly and fairly on these complaints. However, the decision as to whether the charges are so serious as to warrant a hearing and a stay of the grant should rest within the Commission's discretion. If the Commission's discretion is abused, the court of appeals is available to correct this abuse.

\section{IV}

\section{Right to Intervene Under Section 309(b)}

Another problem of interpretation under the $195^{2}$ amendments, which has proved unnecessarily troublesome, has been that of determining who is entitled to intervene in cases designated for hearing. The intervention provision of the Act, section 309 (b), 81 permits all "parties in interest" to intervene, all with full hearing rights. Section 309 (b) provides, in pertinent part, as follows:

If the Commission, after considering such reply, shall be unable to make the finding specified in subsection (a), it shall formally designate the application for hearing on the grounds or reasons then obtaining and shall notify the applicant and all other known parties in interest of such action and the grounds and reasons therefor, specifying with particularity the matters and things in issue but not including issues or requirements phrased generally. The parties in interest, if any, who are not notified by the Commission of its action with respect to a particular application may acquire the status of a party to

${ }^{80}$ S. 1577 (in Commerce Committee) and H.R. 4816 (in Commerce Committee), 85th Cong., Ist Sess. (1957).

${ }^{81} 66$ STAT. 715, 47 U.S.C. $\$ 309$ (b) (1952). 
the proceeding thereon by filing a petition for intervention showing the basis for their interest at any time not less than ten days prior to the date of hearing. Any hearing subsequently held upon such application shall be a full hearing in which the applicant and all other parties in interest shall be permitted to participate but in which both the burden of proceeding with the introduction of evidence upon any issue specified by the Commission, as well as the burden of proof upon all such issues, shall be upon the applicant.

It will be noted that the sole test of a proposed intervenor is that he file a petition showing the "basis of [his] interest."

Obviously, the term "parties in interest" in this subsection means the same thing as it does in connection with protest cases under section 309 (c); thus, all the case law defining "parties in interest" in protest cases is equally applicable to this subsection. One whose claimed right of intervention is based upon objectionable interference had clearly established intervention rights long prior to the 1952 amendments. ${ }^{82}$ So it is only where intervention is based on economic injury that any problems have arisen.

Prior to 1939 , the Commission permitted persons alleging that economic injury would be caused by the grant of a certain application to intervene in the hearing as of right. However, in I939, a specific rule was adopted by the Commission, severely limiting this right. ${ }^{83}$ In substance, this discretionary rule provided that if a person sought intervention-on grounds other than electrical interference-then the petition to intervene must show the nature of petitioner's interest and must show how such person's participation would assist the Commission in the determination of the issues. The Commission also reserved the right to permit intervention limited either as to issues or as to the stages of the proceeding. This discretionary rule, where intervention was based on economic injury, has consistently been followed since 1939 and, in fact, continued to be followed even after the passage of the $195^{2}$ amendments.

The language of the new section 309 (b) has severely limited the Commission's discretion in these cases. Yet, in the first case arising after passage of the new section, the Commission refused to permit intervention; not because the intervenor failed to show it was a party in interest, but because it had not shown how its participation would assist the Commission in deciding the case. ${ }^{84}$ Thus, the Commission used the same discretionary rule it had been applying since I939. This same principle was applied in other cases, and intervention was permitted only where the intervenor set forth with particularity the nature of his proposed participation and the benefit thereof. ${ }^{85}$ Also, the Commission applied the other facet of its discretionary intervention rule, permitting in some cases intervention on a limited basis only. ${ }^{80}$ As the Commission said in one case ${ }^{87}$

The extent of an intervenor's participation is limited by his interests on the basis of ${ }^{82}$ FCC v. NBC (KOA), 319 U.S. 239 (1943). $\quad$ sa See Hazelwood, 7 F.C.C. 443,444 (1939).

84 Niagara Frontier Amusement Corp., ro R.R. 39 (1954).

${ }^{8 \sigma}$ Independent Television, to R.R. 510 (1954); Allegheny Broadcasting Corp., 1o R.R. I18I (1954).

${ }^{86}$ See, e.g., St. Louis Telecast, Io R.R. II85 (1954).

${ }^{87}$ Allegheny Broadcasting Co., Io R.R. I181, Ix84 (1954). 
which he has obtained status as a party in interest, and he cannot explore issues with respect to which he does not have an interest.

Finally, this problem came before the court of appeals. In Key Broadcasting System, ${ }^{88}$ the Commission denied a petition to intervene, finding the the statement of matters set forth was "conjectural and speculative and otherwise insufficient in that it does not adequately state the nature of the facts it proposes to develop at the hearing." The party seeking intervention appealed, claiming that since it was a party in interest based on alleged economic injury, it was entitled as of right to intervene, regardless of what facts it would develop in the hearing and whether or not its participation would be helpful. The court of appeals agreed with the appellant's position and reversed the Commission. The court concluded that the language of section $309(\mathrm{~b})$ requires only that "potential intervenors show the facts demonstrating that they are 'parties in interest." When that showing is made, "the Commission has exhausted its discretion; it may not deny intervention to a party in interest merely because it thinks his participation would not aid its decisional process." ${ }^{29}$ This decision has now clarified the intervention question. There still remains the subsidiary question of whether or not, once entitled to intervene, the intervenor has the right to participate on all issues, or whether the Commission has power to limit his participation. The rationale of the Elm City case, as well as the language of section $309(\mathrm{~b})$, would seem to indicate that if once found to be a party in interest, then the intervenor can participate on all phases of the case.

The requirements of the new section 309 (b), as interpreted by the Elm City case, have effectively destroyed the Commission's discretion. It is literally true that any hearing is now open to participation by a number of different parties whose primary interest is not in determining the proper party to receive the grant, but rather in delaying a grant to anybody for as long a period as possible. Here, again, it is believed that some discretion should rest with the Commission to limit the number of persons who can participate and to limit the scope of their participation. The 1952 amendments, by destroying this discretion, have only caused delay, expense, and more lengthy proceedings.

\section{$\mathrm{V}$}

\section{"ECONOMIC INJURY" Protests}

One of the most insidious by-products of the 1952 amendments-and a totally unforeseen one-has been the continued assertion of the principle that economic injury to existing stations may be, under certain circumstances, a basis for denying a new grant. It will be recalled that in the case of FCC $v$. Sanders Bros. Radio Station, the Court adopted two principles: (I) economic injury to an existing station, apart from public interest considerations, is not a factor the Commission must consider in passing on new applications, and (2) economic injury is sufficient to show standing as

\footnotetext{
${ }^{88}$ See Elm City Broadcasting Corp. v. United States, 235 F.2d 811, 814 (D.C. Cir. I956).
}

${ }^{20} \mathrm{Id}$. at 816 . 
a party in interest. The Supreme Court emphasized that broadcasting was a business of free competition and not regulated like common carriers; that it was the intention of Congress "to permit a licensee who is not interfering electrically with other broadcasters to survive or succumb according to his ability to make his programs attractive to the public." The Court added a cautionary word to the effect that questions of competition were not to be entirely disregarded, for such questions ${ }^{00}$

... may have a vital and important bearing upon the ability of the applicant adequately to serve his public; it may indicate that both stations-the existing and the proposedwill go under, with the result that a portion of the listening public will be left without adequate service; it may indicate that, by a division of the field, both stations will be compelled to render inadequate service.

This cautionary language has formed the basis recently for a general assault on the basic principle that economic injury to an existing station is not a grounds for denying a new license. Many protests since the 1952 amendments have claimed that the adverse effects which new competition will have in their market are so serious as to involve public interest considerations and that even though the protestants personally are lawfully entitled to no protection, the public will suffer grievous injury and loss of service if a new station is permitted to operate in their market. $^{91}$

The Commission has been entirely unsympathetic with these assertions. In fact, these arguments were not new. They began almost immediately after the Sanders decision in 1940. But the Commission had consistently refused to consider them. ${ }^{92}$ As late as 1950, in the case of Voice of Cullman, ${ }^{93}$ the Commission expressly refused to consider the economic effect which would be caused by the entry into the market of a second station. The decision was based on policy grounds: broadcasting, being a business of free competition, inevitably involves the risk of failure, and any prediction of what effect new competition will have in the future is so totally speculative and conjectural that the Commission ought not to engage in such "crystal ball gazing."

This decision appeared to set the matter at rest. But with the passage of the I952 amendments and the tremendous emphasis placed therein upon the procedural rights of existing stations to object to new grants, once again the principle of freedom from competition, rather than freedom of competition, began to emerge. It is fair to conclude that since the adoption of the 1952 amendments, the Commission has handled this problem very poorly. This principle was urged very shortly after adoption of the new section 309 (c). Yet, it was not until March 1957 that the Commission finally issued a definitive opinion disposing of the question. For

${ }^{90} 3.09$ U.S. at $475-76$.

${ }^{01}$ See, e.g., Radio Tifton (WTIF), II R.R. 1167, 12 R.R. 675 (1955); Southeastern Enterprises (WCLE), I2 R.R. 578 (1955).

${ }^{90}$ See, e.g., Telegraph Hcrald (KDTH), 8 F.C.C. 322 (1940); Presque Isle Broadcasting Co., 8 F.C.C. $3(1940)$.

${ }^{03} 6$ R.R. 164 (1950). 
almost five years, these cases kept arising to plague the Commission and the public and to delay the advent of new and needed service.

Despite the Commission's vacillation and indecision, it is not wholly to blame; the amendments, themselves, contributed to the emergence of this principle of freedom from competition. If economic injury gives one the right to object, protest, or intervene, it becomes extremely difficult to prevent such objector from asserting that very injury as a basis for denial of the grant in issue. Of course, the objector will clothe his objections in "public interest" terms, but basically, the ultimate end sought is the denial or delay of the new grant, so that the existing station can retain unmolested its economic position in the market. To some in the broadcasting business, this has been an extremely unfortunate development. Persons who are losing money are encouraged to utilize the protest procedures to reduce their deficits at the expense of the public. Persons who are doing handsomely as monopolists in their markets are encouraged to protest so as to protect their monopoly. Once the principle is established-however innocently-that the Commission will protect competitors under some conditions, then there is no end to the clamor for protection at all levels, under all conditions. What is now a free industry will become a regulated industry. Most broadcasters would agree that they would rather run the risks inherent in a free competitive system than accept a regulated economy such as is now applicable to common carriers. It is, therefore, extremely unfortunate that the 1952 amendments have created an atmosphere whereby certain broadcasters are encouraged to utilize commission procedures as a means of securing government protection solely for their private interests.

Fortunately, in March 1957, the Commission handed down a decision which should have the effect of discouraging once and for all these economic protests where protection is sought against further competition. In the case of Southeastern Enterprises (WCLE), ${ }^{94}$ the Commission expressly refused to consider the question of competition stating that:

We take this opportunity now to disclaim any power to consider the effects of legal competition upon the public service in the field of broadcasting.

This was an extremely strong statement; before this case, the refusal to consider economic questions had rested solely on policy grounds, not on any asserted lack of legal authority. ${ }^{95}$ There has been considerable criticism that the Commission went too far in the Southeastern Enterprises case. However, if it did, and no court has yet considered the question, ${ }^{90}$ the harm has been minimized by certain decisions issued since the Southeastern Enterprises case. In these later cases, the Commission has added an alternative ground to its claimed lack of legal authority to consider eco-

04 22 F.C.C. 605, 13 R.R. I39 (1957). ${ }^{05}$ Voice of Cullman, 6 R.R. I64 (I950).

${ }^{86}$ Two abortive attempts were made to challenge the Southeastern Enterprises decision in the court of appeals: Television Corporation of America v. FCC, No. 13,803; Fitch \& Kyle v. FCC, No. 13,868 (D.C. Cir. June 5, 1957). In both cases, after losing requests for stays in the court of appeals, the protestants dismissed their appeals. 
nomics; it now holds that even if it had the legal authority, it would not exercise it as a matter of policy, citing the Voice of Cullman case. ${ }^{97}$

Thus, both as a matter of law and policy, the Commission has now decided it will not consider the effects of competition upon existing stations in determining whether to grant new licenses. Nevertheless, the 1952 amendments still give substantial procedural rights based solely on the economic interests of the person asserting the rights. In many of these situations, the Commission's discretion is still severely limited. It is believed, therefore, that until the $195^{2}$ Act is amended further to increase the Commission's discretion, the emphasis upon competitive injury still looms too large in the regulatory scheme.

\section{VI}

\section{Conclusion}

There has been an attempt to set forth in the preceding pages the results of five years' experience under the Communications Act Amendments, 1952. It is believed that in large part, these amendments have failed to accomplish their purpose and have, in fact, caused delay, expense, and hardship. There are many provisions in the 1952 amendments which have not been discussed. These, by and large, have been of substantial benefit. For example, the provision of section $312,{ }^{98}$ whereby the Commission was given the power to issue "cease and desist" orders, has been of value in that it has increased the flexibility with which the Commission can deal with violators of the Act and Rules. ${ }^{99}$ So also, certain provisions pertaining to the appeal sections of the Act, section $402(a)$ and (b) ${ }^{100}$ have clarified the law and simplified the appeal procedures. This also is beneficial. Indeed, certain features of the sections discussed and criticized in some detail above have been of value to the administrative process.

Despite these and other advantages resulting from the 1952 amendments, it is believed generally the major fault of the amendments has been that too much discretion has been taken away from the Commission. There is no other governmental agency which operates within so confining a procedural framework. Experience shows that the withdrawal of discretionary powers does not make for a better administration or a fairer result. The true answer lies in an informed agency conscientiously exercising its authority in a fair and judicious manner. Essential to this objective is a delegation of sufficiently broad authority, so that the Commission can intelligently and fairly cope with the complex problems of this dynamic industry.

${ }^{87} 6$ R.R. I64 (1950). Kaiser Hawaiian Village Radio, 22 F.C.C. 941, 15 R.R. 84a (1957); West Georgia Broadcasting Co. (WWCS), r4 R.R. 275 (I957).

${ }^{88} 66$ STAT. 716,47 U.S.C. $\$ 312$ (1952).

${ }^{90}$ C. J. Community Services, Inc., v. FCC, 246 F.2d 660 (D.C. Cir. 1957).

${ }^{100} 66$ STAT. 7I8, 47 U.S.C. $\$ 402$ (1952). 